\title{
Hubungan antara Aktivitas Melipat Kertas dengan Kemampuan Motorik Halus Anak Usia Dini
}

\section{Elia Tarlina}

Pendidikan Islam Anak Usia Dini, Universitas Islam Negeri Sunan Gunung Djati Bandung Jalan Soekarno Hatta Cimincrang Gedebage Bandung 406294

Email: eliatarlina@gmail.com

$$
\text { Naskah diterima: } 31 \text { Juli 2019, direvisi: } 11 \text { September 2019, diterbitkan: } 27 \text { September } 2019
$$

\begin{abstract}
Abstrak
Hasil studi pendahuluan di kelompok B2 RA Al-Wafi menunjukkan bahwa, terdapat beberapa permasalahan yang terkait dengan kemampuan motorik halus yang belum berkembang secara optimal seperti saat menggunting pola hasilnya belum rapi tidak mengikuti garis sesuai pola. Dalam kegiatan menggambar, anak masih kaku memegang krayon sehingga hasilnya masih keluar garis. Kondisi demikian merupakan masalah yang menarik untuk diteliti. Tujuan penelitian ini adalah untuk mengetahui realitas aktivitas melipat kertas, realitas kemampuan motorik halus dan realitas hubungan antara aktivitas melipat kertas dan kemampuan motorik halus. Metode yang digunakan yakni kuantitatif korelasional. Teknik pengumpulan data pada penelitian ini adalah melalui lembar observasi dan dokumentasi. Adapun hasil perhitungan pada variabel X diperoleh nilai rata-rata sebesar 72 . Nilai tersebut berada pada interval 70-79 dengan kategori baik. Sedangkan, pada variabel Y diperoleh nilai rata-rata 78. Nilai tersebut berada pada interval 70-79 dengan kategori baik. Hubungan antara ativitas melipat kertas dengan kemampuan motorik halus anak usia dini diperoleh angka koefisien korelasi sebesar 0,99. Angka koefisien korelasi ini termasuk pada kategori kuat/tinggi karena berada pada interval 0,800-1,000. Hasil uji signifikansi diperoleh harga $t_{\text {hitung }}=28,28$ dan $t_{\text {tabel }}=2,120$. Artinya terdapat hubungan yang signifikan antara aktivitas melipat kertas dengan kemampuan motorik halus anak usia dini. Adapun besarnya kontribusi/pengaruh aktivitas melipat kertas terhadap motorik halus anak usia dini sebanyak $86 \%$. Hal ini menunjukkan bahwa $14 \%$ kemampuan motorik halus anak usia dini dipengaruhi oleh faktor lain.
\end{abstract}

Kata kunci: anak usia dini, melipat kertas, motorik halus. 


\begin{abstract}
The results of a preliminary study in $B 2 \mathrm{R} A \mathrm{Al}$-W afi group showed that, there were several problems related to fine motor skills that had not been developed optimally such as when cutting patterns the results were not neat and did not follow the lines according to the pattern. In drawing activities, children are still stiff holding the crayons so the results are still out of line. This condition is an interesting problem to study. The purpose of this study was to determine the reality of paper folding activities, the reality of fine motor skills and the reality of the relationship between paper folding activities and fine motor skills. The method used is quantitative correlational. Data collection techniques in this study were through observation and documentation sheets. The results of calculations on the variable $X$ obtained an average value of 72 . The value is in the 70-79 interval with a good category. Meanwhile, the Y variable obtained an average value of 78. The value is in the 70-79 interval with a good category. The relationship between paper folding activities with fine motor skills of early childhood obtained by a correlation coefficient of 0.99 . This correlation coefficient number is included in the category of strong / high because it is in the interval 0,800-1,000. Significance test results obtained tcount $=28.28$ and ttable $=2.120$. This means that there is a significant relationship between paper folding activities with fine motor skills in early childhood. The magnitude of the contribution / effect of paper folding activities on early motor fine children as much as $86 \%$. This shows that $14 \%$ of early childhood motor skills are influenced by other factors.
\end{abstract}

Keywords: early childhood, paper folding, fine motor skills.

\title{
Pendahuluan
}

Pendidian anak usia dini (PAUD) adalah jenjang sebelum pendidikan dasar yang merupakan suatu upaya pembinaan yang ditujukan bagi anak sejak lahir sampai usia 6 tahun. Undang-undang Nomor 20 Tahun 2003 pasal 28 ayat 1 tentang Sistem Pendidikan Nasional menyebutkan bahwa pendidikan anak usia dini diselenggarakan sebelum jenjang pendidikan dasar, melalui jalur pendidikan formal (taman kanak- kanak, raudhatul athfal atau bentuk lain yang sederajat), jalur pendidikan nonformal (kelompok bermain, taman penitipan anak atau bentuk lain yang sederajat), dan jalur pendidikan informal yang berbentuk pendidikan keluarga atau pendidikan yang diselenggarakan oleh lingkungan. Dapat disimpulkan bahwa pendidikan anak usia dini adalah proses pemberian rangsangan pendidikan yang bertujuan untuk membina, menumbuhkan dan mengembangkan seluruh aspek dan potensi anak usia dini secara optimal sehingga terbentuk perilaku dan kemampuan dasar sesuai dengan tahap perkembanganya untuk memasuki jenjang pendidikan selanjutnya. 
Setiap anak memiliki aktivitas yang berbeda-beda. Aktivitas ini memiliki pengaruh terhadap kegiatan yang dilakukan setiap anak. Aktivitas yang dilakukan dapat berupa kegiatan yang bersifat jasmani maupun rohani. Anak usia dini tidak terlepas dari segala aktivitas yang berkaitan dengan tumbuhkembangnya. Hal ini karena aktivitas yang dilakukan sehari-hari oleh anak merupakan salah satu faktor yang penting dalam menumbuhkembangkan segala potensi yang dimiliki anak. Berdasarkan pendapat Djamarah (2008: 38) bahwa aktivitas adalah kegiatan atau keaktifan, jadi segala sesuatu yang dilakukan atau kegiatan-kegiatan yang terjadi baik fisik maupun non fisik merupakan aktivitas. Aktivitas anak selama proses belajar maupun bermain merupakan salah satu indikator adanya keinginan anak untuk melakukan sesuatu. Dengan demikian perlu adanya aktivitas yang dapat merangsang pertumbuhan dan perkembangan anak usia dini.

Perkembangan motorik menjadi salah satu aspek terpenting dalam pendidikan anak usia dini karena perkembangan motorik merupakan suatu gerakan yang melibatakan otototot besar maupun otot-otot halus artinya kemampuan motorik sebagai perkembangan unsur kematangan dan pengendalian gerak tubuh. Perkembangan motorik dibagi menjadi dua bagian diantaranya motorik kasar dan motorik halus, motorik kasar melibatkan gerakan otototot besar seperti berlari, meloncat, melompat, berjalan, dan lain-lain. Sedangkan motorik halus melibatkan sebagian otot-otot halus seperti menulis, menggambar, melipat, dan lainlain. Perkembangan motorik halus yang mengalami masalah dapat ditangani dengan stimulus yang diberikan baik oleh guru maupun orangtua. Salah satu aktivitas yang dapat digunakan untuk menstimulus perkembangan motorik halus anak yaitu melalui aktivitas melipat kertas. aktivitas melipat kertas merupakan kegiatan keterampilan tangan untuk menciptakan bentukbentuk tertentu tanpa menggunakan bahan perekat (lem). Kegiatan ini membutuhkan koordinasi antara mata dan tangan, ketelitian, kerapihan, dan kreativitas MS Sumantri (2005: 151).

Berdasarkan studi pendahuluan, aktivitas melipat kertas yang dilaksanakan di RA AlWafi Panyileukan Kota Bandung ternyata sangat mendukung terhadap kemampuan motorik halus, baik dari keterampilan tangan sehingga dapat melenturkan otot-otot halus maupun kreativitas yang dapat menghasilkan suatu bentuk-bentuk tertentu. Meskipun aktivitas melipat kertas sudah dilaksanakan di sekolah dengan baik serta memberikan rangsangan positif terhadap anak untuk melatih kemampuan motorik halusnya, namun di sisi lain terbukti bahwa terdapat sebagian kecil anak yang memiliki kendala dalam perkembangan motorik halus anak yang belum berkembang secara optimal seperti saat menggunting pola hasilnya 
belum rapi tidak mengikuti garis sesuai pola. Dalam kegiatan menggambar, anak masih kaku memegang krayon sehingga hasilnya masih keluar garis. Kondisi demikian merupakan masalah yang menarik untuk diteliti.

Berdasarkan fenomena tersebut, maka munculah permasalahan yang perlu dikaji lebih dalam, yaitu bagaimana aktivitas melipat kertas yang ada di sekolah, bagaimana kemampuan motorik halus anak usia dini, dan bagaimana pula hubungan keduanya. Dalam upaya merealisasikan permasalahan tersebut, maka penulis mengangkatnya ke dalam kegiatan penelitian, melalui sebuah judul: "Hubungan antara Aktivitas Melipat Kertas dengan Kemampuan Motorik Halus Anak Usia Dini” (Penelitian pada Kelompok B2 RA Al-Wafi Panyileukan Kota Bandung). Tujuan dari penelitian ini adalah untuk mengetahui adanya hubungan antara aktivitas melipat kertas dengan kemampuan motorik halus anak usia dini.

\section{Metodologi}

Pendekatan dalam penelitian ini adalah pendekatan kuantitatif, karena penelitian ini disajikan dengan angka-angka. Metode penelitian ini adalah metode deskriptif analitik melalui pendekatan kuantitatif dengan menggunakan teknik korelasi. Deskripif merupakan metode yang diarahkan untuk memecahkan masalah dengan cara memaparkan atau menggambarkan apa adanya (Sudjana, 2005: 7).

Jenis penelitian ini menggunakan korelasional. Korelasional bertujuan untuk mengetahui sejauh mana variasi dalam suatu faktor atau karakteristik berhubungan dengan variasi dalam faktor atau karakteristik lainnya. Penelitian ini mensyaratkan pengukuran beberapa variabel yang saling berhubungan secara simultan. Kekuatan hubungan antara variabel satu dengan variabel lainnya digunakan indeks yang disebut koefisien korelasi yang diberi simbol $\mathrm{r}$. Harga koefisien korelasi berkisar antara 0 sampai 1 untuk hubungan positif dan sampai -1 bila hubungannya negatif (Maolani \& Cahyana, 2015: 78).

Arikunto (2013: 173) mengatakan populasi adalah keseluruhan subjek penelitian. Populasi pada penelitian ini yaitu kelompok B di RA Al-Wafi Panyileukan Kota Bandung yang terdiri dari 3 kelas dengan jumlah total 55 anak. Sampel penelitian ini adalah sebagian yang diambil dari seluruh objek yang diteliti yang dianggap mewakili seluruh populasi dan diambil dengan menggunakan teknik tertentu (Taniredja \& Mustaidah, 2012: 34). Teknik pengambilan sampel dalam penelitian ini adalah probability sampling (random sample), yang berarti teknik penentuan sampel secara random atau acak. Sampel yang dibutuhkan dalam 
penelitian ini adalah satu kelas. Pemilihan kelas ini berdasarkan pertimbangan kepala sekolah yang mengetahui karakteristik dari setiap kelas. Penelitian ini dilaksanakan di kelompok B2 RA Al-Wafi Panyileukan Kota Bandung. Sumber data pada penelitian ini adalah siswa-siswi yang berjumlah 18 anak.

Teknik pengumpulan data yang digunakan dalam penelitian adalah observasi dan dokumentasi. Observasi yaitu pengamatan yang dilakukan dengan cara mengadakan pengamatan terhadap objek, baik langsung maupun tidak langsung (Sudjana, 2002: 18). Berdasarkan masalah yang dihadapi, maka dilaksanakan observasi yang dihimpun meliputi proses penyalinan data yang akan memberikan informasi tentang penelitian. Observasi ini digunakan untuk mengetahui data variabel $\mathrm{X}$ yaitu aktivitas melipat kertas dan variabel $\mathrm{Y}$ yaitu kemampuan motorik halus pada anak usia dini. Observasi dilakukan oleh peneliti pada saat proses pembelajaran berlangsung yang kemudian akan dilakukan analisis data dengan menggunakan statistik.

Dokumentasi adalah mencari data mengenai hal-hal atau variabel yang berupa catatan, transkip, buku, notulen rapat, leger nilai, agenda dan lain-lain (Dimyati, 2013: 98) dengan demikian metode dokumentasi adalah metode pengumpulan data dengan jalan mengumpulkan data-data tertentu melalui catatan, dokumen, ide dan pendapat seseorang sebagai sumber informasi yang diperlukan peneliti dalam penelitiannya, baik berupa data jumlah peserta didik, leger nilai dan lain sebagainya. Dokumentasi yang dibutuhkan dalam penelitian ini meliputi foto tentang berjalannya kegiatan penelitian dan data-data yang mendukung lainnya. Data yang diperoleh dari dokumen ini bisa digunakan untuk melengkapi bahkan untuk memperkuat data dari hasil observasi.

Pada lembar atau pedoman observasi diperlukan adanya skala penilaian untuk mengukur aktivitas anak yang berkenaan dengan melipat kertas dan kemampuan motorik halusnya. Dengan menggunakan skala penilaian maka nilai variabel yang diukur dengan instrumen dapat dinyatakan dalam bentuk angka. Skala penilaian dalam penelitian ini adalah dengan menggunakan skala empat perkembangan anak yaitu: BB (Belum Berkembang), MB (Mulai Berkembang), BSH (Berkembang Sesuai Harapan) dan BSB (Berkembang Sangat Baik) (Suminah, 2015: 5).

Analisis data dilakukan melalui langkah-langkah sebagai berikut: 1) analisis parsial, analisis ini dimaksudkan untuk menguji dan menghitung skor rata-rata indikator variabel X dan variabel Y. 2) analisis korelasi, koefisien korelasi adalah bilangan atau angka yang menyatakan besar kecilnya hubungan. Koefisien korelasi itu bergerak antara 0,00 sampai 
$+1,00$ atau antara 0,00 sampai $-1,00$ atau $+1,00$ sampai $-1,00$. Koefisien yang bertanda positif mennjukkan arah korelasi positif dan koefisien negatif menunjukkan arah korelasi negatif. Sedangkan koefisien yang bernilai 0,00 menunjukkan tidak ada hubungan antara variabel $\mathrm{X}$ dan variabel Y (Hayati, 2014). Koefisien korelasi biasanya diberi simbol r (korelasi Product Moment) atau $\varrho$ (dibaca rho, korelasi Rank) dan karena kedua komponen masing-masing ditandai dengan huruf $\mathrm{X}$ dan $\mathrm{Y}$, maka koefisien korelasinya disingkat menjadi rxy. Oleh karena itu setelah data terkumpul, sebelum menilai hubungan antara dua variabel yang diteliti, harus dihitung terlebih dahulu koefisien korelasinya. Berdasarkan ketentuan di atas mengenai persyaratan analisis statistik parametris, maka data yang diperoleh diuji normalitas danregresi linier terlebih dahulu untuk mengetahui data tersebut berdistribusi normal atau tidak menggunakan Chi Kuadrat ( $\chi 2)$.

\section{Hasil dan Diskusi}

Berdasarkan hasil penelitian, aktivitas melipat kertas di kelompok B2 RA Al-Wafi termasuk kategori baik. Hal in terlihat dari analisis parsial yang menunjukkan bahwa nilai rata-rata aktivitas melipat kertas adalah 72 dan berada pada interval 70 - 79 yang artinya baik. Sementara itu, berdasarkan hasil perhitungan diperoleh mean $=72,39$; median $=70,8$; modus $=67,65$ dan standar deviasi $=11,88$, nilai chi kuadrat $(\chi 2)$ hitung $=3,37$; dan chi kuadrat $(\chi 2)$ tabel $=7,815$ dengan $\mathrm{db}=3$ pada taraf signifikansi $5 \%$. Karena $\left(\chi^{2}\right)$ hitung $=3,37>\left(\chi^{2}\right)$ tabel $=7,815$, maka data tentang aktivitas melipat kertas berdistribusi normal.

Selanjutnya berdasarkan hasil penelitian terhadap kemampuan motorik halus anak usia dini di kelompok B2 RA Al-Wafi sudah termasuk ke dalam kategori baik. Hal ini ditunjukkan dari analisis parsial yang menunjukkan angka 78 yang berada pada interval $70-79$ yang artinya berkualifikasi baik. Hasil perhitungan kemampua motorik halus anak usia dini diperoleh mean $=78,11 ;$ median $=71,5 ;$ modus $=58,28 ;$ dan standar deviasi $=11,31$. Nilai chi kuadrat $(\chi 2)$ hitung $=7,78$; dan chi kuadrat $(\chi 2)$ tabel $=7,815$ dengan db $=5$ pada taraf signifikansi 5\%. Karena $(\chi 2)$ hitung $=7,78>(\chi 2)$ tabel $=7,815$, maka data tentang kemampua motorik halus anak usia dini berdistribusi normal.

Aktivitas menjadi peran penting dalam melakukan kegiatan belajar maupun bermain, karena aktivitas mencakup segala kegiatan yang dilaksanakan baik kegiatan jasmani maupun rohani (Rosalia, 2005: 2). Anak yang aktif akan memiliki keterlibatan dalam melakukan aktivitas karena untuk merubah tingkah laku serta dapat menghasilkan sesuatu. Aktivitas ini untuk melatih peserta didik aktif dalam mengerjakan dan membuat sesuatu, sesuai pendapat 
Froebel (Ningtyas: 2017) bahwa pendidik harus membuat metode yang banyak memberikan kesempatan kepada peserta didik untuk sibuk dan aktif mengerjakan, membuat dan menciptakan sesuatu atau inisiatif sendiri seperti kegiatan melipat kertas.

Kemampuan motorik halus anak usia dini merupakan keterampilan yang dimiliki anak dalam mengkoordinasikan sekelompok otot-otot kecil seperti jemari dan tangan yang sering membutuhkan kecermatan dan koordinasi antara mata dan tangan. Koordinasi antara mata dan tangan dapat ditingkatkan melalui kegiatan permainan membentuk atau memanipulasi benda-benda dari adonan tanah liat/lilin, menggambar, mewarnai, menempel, menggunting, melipat, memotong, merangkai benda dengan benang atau disebut juga dengan meronce (Sumantri: 145).

Kata keterampilan sama artinya dengan kata cekatan. Terampil atau cekatan menurut Soemarjadi, Muzni Ramanto, dan Wikdati Zahri (1993: 2) adalah kepandaian ataupun kemampuan untuk melakukan suatu pekerjaan dengan cepat dan benar. Pengembangan keterampilan motorik halus ini akan berpengaruh terhadap kesiapan anak dalam menulis, kegiatan melatihkan koordinasi antara mata dan tangan yang dianjurkan dalam jumlah waktu yang cukup meskipun penggunaan tangan secara utuh belum mungkin tercapai tetapi harus melakukan banyak latihan supaya kemampuan dalam motorik halusnya berkembang secara optimal.

Setelah diketahui hasil pengolahan data dari aktivitas melipat kertas dan kemampuan motorik halus anak usia dini, berikutnya akan dilihat hubungan antara aktivitas melipat kertas dengan kemampuan motorik halus anak usia dini. Hasil penelitian mengenai hubungan antara aktivitas melipat kertas dengan kemampuan motorik halus anak usia dini di kelompok B2 RA Al-Wafi Panyileukan Kota Bandung adalah ada hubungan (korelasi) antara keduanya. Hal ini ditunjukkan oleh harga koefisien korelasi sebesar 0,99 yang berada pada tingkat hubungan yang kuat/tinggi karena berada pada interval koefisien 0,800 - 1,000.

Hal ini ditunjukkan pula oleh hasil pengujian hipotesis diperoleh harga $t_{\text {hitung }}$ yaitu 28,28 dan $t_{\text {tabel }}$ dengan $d b=16$ pada taraf signifikansi 5\% sebesar 2,120. Oleh karena itu, dapat diambil kesimpulan bahwa $\mathrm{t}_{\text {hitung }}=28,28>\mathrm{t}_{\text {tabel }}=2,120$ maka dapat diinterpretasikan hipotesis alternatif $(\mathrm{Ha})$ diterima, artinya terdapat hubungan yang signifikan antara aktivitas melipat kertas (variabel X) dengan kemampuan motorik halus anak usia dini (variabel Y) pada kelompok B2 RA Al-Wafi Panyileukan Kota Bandung.

Berdasarkan hasil analisis koefisen determinasi yang telah dilakukan sebelumnya, maka dapat disimpulkan bahwa tingkat kebenaran terjadinya korelasi antara aktivitas melipat kertas 
dengan kemampuan motorik halus anak usia dini sebanyak 86\%. Sebaliknya tidak akan terjadinya korelasi sebesar 14\% atau dengan kata lain aktivitas melipat kertas akan mempengaruhi kemampuan motorik halus anak usia dini sebesar 86\% dan 14\% lagi kemampuan motorik halus anak usia dini dipengaruhi oleh faktor lain.

Berdasarkan data tersebut dapat diambil kesimpulan bahwa aktivitas melipat kertas berkaitan erat dengan kemampuan motorik halus anak usia dini karena aktivitas ini melibatkan adanya gerakan jari jemari tangan yang akan membentuk dan dapat menghasilkan sesuatu. Sesuai pendapat Sumanto (2003: 99-100) bahwa melipat kertas adalah suatu teknik kerajinan tangan dengan tujuan untuk menghasilkan aneka bentuk mainan, hiasan, benda fungsional dan kreasi lainnya. Kegiatan ini sangat cocok untuk anak usia dini, selain anak dapat terbiasa dalam menciptakan hal-hal baru atau inovasi anak juga akan terbiasa dalam melakukan gerakan tangan ketika membuat lipatan.

\section{Penutup}

Berdasarkan hasil penelitian dan pembahasan mengenai aktivitas melipat kertas dengan kemampuan motorik halus anak usia dini di RA Al-Wafi Panyileukan Kota Bandung maka dapat disimpulkan sebagai berikut: 1) Aktivitas melipat kertas pada anak usia dini di kelompok B2 RA Al-Wafi Panyileukan Kota Bandung berada pada kategori baik dengan angka 72 yang berada pada interval 70-79. Hal ini berarti mayoritas anak memiliki aktivitas melipat kertas yang baik. 2) Kemampuan motorik halus anak usia dini di kelompok B2 RA Al-Wafi Panyileukan Kota Bandung berada pada kategori baik dengan angka 78 yang berada pada interval 70-79. Hal ini menunjukkan bahwa mayoritas kemampuan motorik halus anak berkualifikasi baik. 3) Hubungan antara aktivitas melipat kertas dengan kemampuan motorik halus anak usia dini di kelompok B2 RA Al-Wafi Panyileukan Kota Bandung menunjukkan harga koefisien korelasi sebesar 0,99 yang berada pada tingkat hubungan sangat kuat/tinggi karena berada pada interval koefisien korelasi 0,800-1,000. Hasil uji hipotesis menunjukkan bahwa $\mathrm{t}$ hitung $=28,28>\mathrm{t}$ tabel $=2,120$. Artinya terdapat hubungan positif antara aktivitas melipat kertas dengan kemampuan motorik halus anak usia dini. Kontribusi yang diberikan aktivitas melipat kertas terhadap kemampuan motorik halus anak usia dini sebesar $86 \%$ dan 14\% lainnya dipengaruhi oleh faktor lain yang tidak diteliti pada penelitian ini. 


\section{Daftar Pustaka}

Arikunto, Suharsimi. (2013). Prosedur Penelitian Suatu Pendekatan Praktik. Jakarta: Rineka Cipta.

Djamarah, Syaiful Bahri. (2008). Psikologi Belajar.Jakarta: Rineka Cipta.

Dimyati, Johni. 2013. Metodologi Penelitian Pendidikan Aplikasinya pada Penidikan Anak Usia Dini (PAUD). Jakarta: Kencana.

Hayati, Tuti. 2014. Pengantar Statistika Pendidikan. Bandung: CV. Insan Mandiri.

Maolani, R.,\& Cahyani, U.(2015). Metodologi Penelitian Pendidikan. Jakarta: Raja Grafindo Persada.

Menteri Pendidikan Nasional. (2003). Undang-undang Republik Indonesia Nomor 20 tentang Sistem Pendidikan Nasional. Jakarta: Departemen Pendidikan Nasional RI.

MS Sumantri. (2005). Model Pengembangan Keterampilan Motorik Anak Usia Dini. Jakarta: Departemen Pendidikan Nasional Direktorat Jendral Pendidikan Tinggi Direktorat Pembinaan Pendidikan Tenaga Kependidikan dan Tenaga Perguruan Tinggi.

Ningtyas, Tia Pratama. (2017). Mengingkatkan Keterampilan Motorik Halus Anak Usia Dini Melalui Kegiatan Melipat Kertas (Origami) Pada Anak Kelompok A TK Aisiyah Bustanul Athfal. Tersedia. (http://journal.umsurabaya.ac.id) Diakses pada: 25 Juni 2019.

Rosalia. (2005). Aktivitas Belajar. Jakarta: PT Rineka Cipta.

Soemarjadi, Muzni Ramanto, \& Wikdati Zahri. (1993). Pendidikan Keterampilan. Jakarta: Departemen Pendidikan Nasional, Direktorat Jendral Pendidikan Tinggi, Direktorat Pembinaan Pendidikan Tenaga Kependidikan dan Perguruan Tinggi.

Sudjana. (2002). Penilaian Hasil Proses Belajar Mengajar. Bandung: Remaja Rosdakaraya.

Sudjana. (2005). Metoda Statistik. Bandung: PT. Tarsito.

Sumanto. (2005). Pengembangan Kreativitas Senirupa Anak TK. Jakarta: Departemen Pendidikan Nasional Direktorat Jendral Pendidikan Tinggi.

Suminah, Enah dkk. (2015). Kerangka Dasar dan Muatan Kurikulum 2013 PAUD. Jakarta: Direktorat Pembinaan PAUD Dirjen PAUD dan Diknas Kemendikbud.

Taniredja, \& Mustafidah. (2012). Penelitian Kuantitatif. Bandung: Alfabeta.

\section{Biodata Penulis}

Elia Tarlina lahir di Garut, 31 Juli 1997, merupakan anak pertama dari pasangan keluarga bapak Daryana dan ibu Wiwi Winengsih yang telah menyelesaikan pendidikan S1 jurusan Pendidikan Islam Anak Usia Dini di Fakultas Tarbiyah dan Keguruan UIN Sunan Gunung Djati Bandung (2019) 